\title{
Status of School Library Development in Bangladesh
}

Dr. M. Nasiruddin Munshi

Associate Professor

Dept. of Information Science \& Library Management

University of Dhaka,

Dhaka 1000, Bangladesh.

Tele. 880-2-9677819 (home); $9661920-59$, ext. 4414 (work)

Fax. 880-2-8615583

E-mail ramanasir@yahoo.com

\section{Introduction}

Bangladesh is one of the developing countries of the Third World with and estimated population of 123.2 million crowded into an area of $1,47,570 \mathrm{sq}$. $\mathrm{km}$. The literacy rate is $48.4 \%$ for the population aged 7 plus and of $62 \%$ for the population aged 15 plus. The library movement of Bangladesh started in the mid-19th century with the establishment of four public libraries in the district towns of Jessore, Bogra, Barishal and Rangpur. Over the last 25 years, a good number of different types of libraries were established in the country, however, the whole picture of library and information systems in Bangladesh is not encouraging.

There are different categories of schools in Bangladesh, i.e. (a) Primary schools (b) Junior secondary schools, and (c) Secondary schools. They all fall into one of the categories below:

1. Public/Government schools (both primary and secondary)

2. Government-aided private schools, and

3. Private schools.

There are about 78,363 primary schools in Bangladesh and among them 37,671 are government primary schools. Among 13,275 secondary schools in Bangladesh, only 317 are government secondary schools. There are also 3287 non-government junior secondary schools in the country. The following table shows the number of schools, teachers and students in Bangladesh as in 2002.

Table-1: Number of Institution, Teachers and Enrolment-2002

\begin{tabular}{|l|c|c|c|c|c|c|}
\hline \multicolumn{2}{|c|}{ Type of School } & Number of & \multicolumn{2}{c|}{ Teacher } & \multicolumn{2}{c|}{ Enrolment } \\
\cline { 4 - 7 } \multicolumn{2}{|c|}{} & Institution & Total & Female & Total & Girls \\
\hline \multirow{2}{*}{$\begin{array}{l}\text { Primary } \\
\text { School }\end{array}$} & Govt. & 37671 & 157236 & 58997 & 10669819 & 5340275 \\
\cline { 2 - 7 } $\begin{array}{l}\text { Junior Sec. } \\
\text { School }\end{array}$ & Non-govt. & 40692 & 157819 & 60443 & 6892009 & 3379906 \\
\cline { 2 - 7 } & Govt. & --- & --- & --- & --- & --- \\
\hline $\begin{array}{l}\text { Secondary } \\
\text { School }\end{array}$ & Govt. & 3287 & 21587 & 3494 & 741776 & 445124 \\
\cline { 2 - 7 } & Non-govt. & 317 & 6954 & 2434 & 221215 & 101964 \\
\hline
\end{tabular}


There is no set official ratio of teacher and student numbers in the school classrooms. Different institutions have their own figures according to their own capacity. It differs from school to school and even one classroom to the other within a school.

The Kudrat-i-Khuda National Education Commission-1974 and M. Maniruzzaman Miah National Education Commission-2003 put emphasis upon the importance of library in education. Unfortunately, the schools in Bangladesh do not have any worthmentioning library at all. There is not even a single school library in 317 government secondary schools and virtually no library exists in primary schools in Bangladesh. A few non-government secondary schools have some form of libraries, but they are mostly unorganized. The collections of these libraries are kept in the shelves under lock and key without any systematic arrangement or supervision of a librarian or a teacher. The average collection of these school libraries is about $500-10,000$ books. They also keep special materials, such as maps, atlases, globes, discs, CDs, etc.

The medium of instruction in Bangladeshi schools is Bangla (mother tongue), except kindergartens and English-medium schools. Most kindergartens, English-medium and international schools are using English as their medium of instruction.

There is only a common method of student assessment in relation to the curriculum that is national examination system in SSC (Secondary School Certificate) level. The methods of assessment from class I to class IX differ from school to school. Other international and English-medium schools follow different methods for assessment according to their own.

There is no national organization or central coordinating body for providing training programmes for the school librarians of Bangladesh. National Academy for Education Management (NAEM) has been proving continuing education programmes for college and madrasah (religious education) librarians of the country. Bangladesh Bureau of Educational Information and Statistics (BANBEIS) and the Library Association of Bangladesh (LAB) have arranged two training programmes for college librarians in 1998 and 2002 respectively. These two training programmes were funded by the UNESCO.

A number of non-government organizations (NGOs) provide training programmes for school librarian in Bangladesh. Human Development Foundation (HDF), Bangladesh has been arranging training programmes on librarianship under "Rural School Library Enrichment Programme (RSLEP)" for non-government school teachers in rural areas since 1986. At a time, HDF selects 50 to 60 non-government schools from different rural areas and one teacher from each school for training programmes. The project period for each school is five years and after every three months each school must report about the progress of their activities. Within the project period, RSLEP contributes about 700 to 800 recreational books for each school to establish a library. So far, HDF has provided training programmes and contributed different reading materials to about 300 rural schools in Bangladesh. Recently, PRAKRITAJAN has started "Training of Secondary School Teachers Under Volunteers for Bangladesh and PRAKRITAJAN School Assistance Programme." They have selected 23 schools from rural areas to provide reading materials for them. 
A few secondary schools were brought under Government Development Programme through the Ministry of Education. These schools received grants from the Ministry of Education for purchasing books. The Ministry also supplies reading resources in some schools in rural areas through the DC's (Deputy Commissioner) office. Asia Foundation donates books and other reading materials to some schools in every year. Islamic Foundation, Bangladesh has been contributing books for schools, colleges, madrasah and mosques regularly. Community Development Library (CDL) has established 26 Rural Information Resource Centres (RIRCs) in different rural areas of Bangladesh for creating reading habits among rural people. Children and school students are especially encouraged to use these resources centres.

\section{Administration and Co-ordination System of School Libraries}

Since there is no formal school library in Bangladesh, there is no school library association in the country. Even there is no college library association in Bangladesh. The government of Bangladesh did not take any initiative for the establishment and development of school libraries in the country. The National Library of Bangladesh is playing the role of a depository of nationally produced publications. It is not contributing for the development of libraries and librarianship in the country. So, it is very much invisible, who is the major stakeholder of school library development in the country? Library Association of Bangladesh (LAB) had taken few initiatives and arranged seminars/conferences for library movement and development of library education and librarianship in Bangladesh. Different Education Commission Reports also strongly recommended and stressed for the establishment libraries in every primary and secondary schools in the country. Unfortunately, the government has not taken any initiative to establish school libraries so far.

\section{Special Projects}

Unfortunately, no special project has been undertaken for the development of school libraries in Bangladesh yet. A few NGOs has been providing funds, reading materials and arranging training programmes for schoolteachers on librarianship on a small scale, but these are grossly inadequate for the overall development of the school libraries.

\section{Problems and Issues of School Libraries in Bangladesh}

The aim of education is to train the students to become responsible citizens who, in future, will take part in the nation building activities. By memorizing, one can pass the examination but, for getting better results in the examination, for enriching one's own knowledge and also for promotion of reading, the importance of school libraries has been recognized by the educationalists, the intellectuals, the social scientists and the like. Unfortunately, the condition of most of the school libraries in Bangladesh is 
deplorable. Without improvement of these libraries, real education can hardly be expected. Following are the major problems of school libraries in Bangladesh:

i. In the present age of information, the whole world has given priority to set up libraries in schools as well as in the communities for creating reading habits of school children; whereas in Bangladesh most of the schools have no library at all.

ii. There is no national commission for school library development in Bangladesh.

iii. Lack of proper initiatives, efforts and plans to establish school libraries by the government at national level. The government has not given any attention to establish the library in the school. As a result, students as well as teachers are not library oriented.

iv. Although different Education Commission Reports stressed to establish library in every school of the country; but the government did not allocate funds for school libraries in the Sixth Five Year Plan (2000-2005) or in the last Annual Development Programme (2004-2005).

v. Some of the non-government and English-medium schools have libraries; however, the authorities are not giving proper attention to improve the facilities and services for students and teachers.

vi. There is no proper salary structure for school and college librarians at the national level. It varies from one institution to another and even within the government departments.

vii. Lack of funds is the most common problem for purchasing books and other reading resources for school libraries in Bangladesh. Sometimes the parent organization allocates limited funds after fulfilling all other needs in the organization.

viii. Absence of a national body or committee to advise government on library and information affairs.

ix. Low professional status, poor working conditions and insufficient infrastructural facilities make the school librarians depressed.

x. Lack of appropriate leadership in library and information profession of the country.

\section{Major Issues}

i. The national development of a country like Bangladesh can not be thought of without the development of libraries and information policy at the national level. The government should give more attention for library 
development as proposed by the National Education Commission Report -2003 by M. Maniruzzaman Miah.

ii. The government should promote the development of a library-based education in the country. Also should promote the organization and development of village and school libraries in Bangladesh.

iii. National Commission for School Library Development in Bangladesh should be established immediately. The commission will advise government on the development of library and information affairs. The commission will also work for the providing benefits and facilities of the library professionals.

iv. Every government and non-government primary and secondary school must have a library and every library must have a professional librarian. $\mathrm{He} /$ she should have at least a graduation degree or one year postgraduate diploma degree in Library and Information Science. Salary for graduation or Masters Degree holders should be of class one scale (Tk. $4,300 /=)$ and for diploma degree holders class two scale (Tk. 3,400/=).

v. A national training institute for library and information science should be established for providing training programmes of professional librarians on the use and application of modern information technology (IT).

vi. Library associations, leading libraries and library educational institutions should organize meetings, seminars, symposia, conferences, lecture series and other programmes in different times to create reading habits among students, teachers and general people of the country.

vii. Every school must have a separate building for its library with sufficient space for library collections and reading room facilities.

viii. The government should allocate funds in the annual budget for the development of school libraries in Bangladesh.

ix. Considering the present situation of school libraries in Bangladesh, a special project should be undertaken by the international donor agencies like World Bank, UNESCO or IFLA for school library development in Bangladesh.

\section{Sources used:}

1. Bangladesh National Scientific and Technical Documentation Centre. Situational Report on National S\&T Information Infrastructures and Services in Bangladesh. Dhaka: BANSDOC, 1996; p. 1.

2. Bangladesh Bureau of Educational Information and Statistics. Pocket Book on Educational Statistics - 2003. Dhaka: BANBEIS, (December, 2003); p. 2. 
3. Library Association of Bangladesh (LAB). National Book Policy: Recommendations of Library Association of Bangladesh. The Eastern Librarians. 17 (1\&2), 1992; pp. 1-14.

4. Bangladesh Bureau of Educational Information and Statistics. Pocket Book on Educational Statistics - 2003. Dhaka: BANBEIS, (December, 2003); pp. 35 .

5. Kudrat-i-Khuda. National Education Commission - 1974. Dhaka: Ministry of Education, 1974; pp. 232-247.

6. Miah, M. Maniruzzaman. National Education Commission - 2003. Dhaka: Ministry of Education, (March, 2004); pp. 295-305.

7. Bangladesh National Scientific and Technical Documentation Centre. Situational Report on National S\&T Information Infrastructures and Services in Bangladesh. Dhaka: BANSDOC, 1996.

8. Human Development Foundation. The Official Records of the Human Development Foundation. Dhaka: HDF, 2004.

9. PRAKRITAJAN. The Official Records of the NGO, Prakritajan. Dhaka: Prakritajan, 2004.

10. Community Development Library. Official Records of the Community Development Library (CDL). Dhaka: CDL, 2004. 